\title{
People-Oriented-Based New Ideas for College Students Management
}

\author{
Chunyan Feng ${ }^{1, a}$, Jingchao Liu²,b* \\ (Xijing University)
}

\author{
${ }^{1}$ Xijing University, No.1 Xijing Road, Chang'an District, Xi'an City, Shaanxi Province, China \\ ${ }^{2}$ Xijing University, No.1 Xijing Road, Chang'an District, Xi'an City, Shaanxi Province, China \\ a704032392@qq.com, bliujingchao@xijing.edu.cn
}

\section{Keywords: People-Oriented; College Students Management; Ideas}

\begin{abstract}
The people-oriented notion has already penetrated into every departments in society, and it is also applied broadly in colleges, no matter in teaching or in management. It is the basic work to maintain the normal education teaching order and to ensure that student's healthy growth. In contemporary society, the college students management under people-oriented ideas has got some progress and presented a series of new ideas. People-oriented management of colleges is to meet the needs of students, giving full play to students' initiative innovation and creativity so that to reach the management objectives that promoting the students' comprehensive development.
\end{abstract}

\section{Introduction}

Nowadays, the development of the world is based on the rapid development of knowledge economy. in this context, every industry faces competition, while talents is the core in all competition and colleges is the cradle of talent cultivation. The management system directly affect the efficiency of university work and school quality. Therefore, with the development of society, colleges and universities should also take corresponding reforms to meet the new situation, new problems, new colleges and new demands in student management.

Along with its continuously improving and systematizing college students management involved a lot advanced thoughts and modes, which sufficiently combined the students management, teaching management and the other aspects in college reflecting the new phenomenon in management work in an even better fashion. For the moment most of the colleges in our country shows their revolution and innovation on management by all means [1]. A series of new thoughts were involved offering an teleological basic for the college students management.

People-oriented college students management ideas is put forwarded just to adapt to this reform requirements, practicing the students management service concepts of all for students, for all students, and for students' everything, comprehensively improving the overall quality of students to meet the needs of today's social development.

\section{The Connotation}

The so-called people-oriented refers to expanding the corresponding work within human-centered. In different situations, the way people behave and think are different. The work guiding philosophy based on human development and needs is people oriented notion. Broadly speaking, the nation can be explained in three aspects.

Firstly, the basis of people-oriented is human development, and the nation is also about human development. No matter under any situation, any mode, human development is the fundamental requirement. Therefore, the development of everything is human development. Secondly human development and human related content which was involved in people-oriented are based on "the majority". The development or progress are on purpose of "the majority". On the other hand, we should also pay attention to the progress of the thinking and other aspects of "the minority". Thirdly, from a philosophical point of view. The people-oriented is a study of the primitive 
problem, and it reflects the independence and the difference on people. From this level, the fundamental problem-the primitive was highlighted [2].

Students are the main constituent part of the school. In the face of the collision and fusion of the multiculturalism in the 21 st century, students are the active and fresh generation. With the budding of students' "personalization" and "subjective" consciousness, the traditional college students management mechanism is becoming powerless, and "people-oriented" management of new ideas is the inevitable trend of college students work.

\section{Theoretical Basis}

Whether from the theoretical point of view or practical, putting people-oriented notion into the college students management has significance and basis. Firstly, from a theoretical perspective , Marxism on the primitive problem of human being is expounded. There is a certain difference between people. Therefore, the human nature, which is the foundation, need to be studied. From the philosophical perspective, people-oriented get different understanding in many countries, but the central points are still around the human and the human development. According to this, people-oriented notion is the foundation of human development and the college students management is also the management for people. From the education management area, the education management has been taking nourishment from western enterprise management theory and practice, The main purpose of the education management is efficiency. With the development of management, education theory of human nature, contemporary education appeared a lot of new ideas, emphasizing the developmental and diversity, emphasizes the understanding and communication, emphasis on democracy and justice, the pursuit of human freedom and liberation, and create value become the general trend of contemporary education management theory.

Secondly, from a practical perspective, practice is the sole criterion for testing truth. [3] Applying the people-oriented notion into the management of college students. Which will be the ideological guidance and practical supervision. Especially students can get comprehensive assessments in practicing.

Third, from the dialectical relationship of people-oriented and efficient management, student management in colleges and universities is an integral part of college education, plays a positive role in talent training. With the improvement of human social civilization degree, the establishment of the humanist management idea is adapted to its law of development. It is the objective necessity of the management of the students in colleges and universities, and the management of university students is the carrier of the idea of the idea of the education. In student management work in colleges and universities, therefore, manifests the humanist management idea, is the fundamental education, and is the basis of establishing scientific management mode, is also the key to the student management work.

\section{The Analysis}

As an important notion in application value and practical significance, people-oriented played an active role in college students management, which not only improved, the concept of shared management of college students, but also provided the guiding work for it.

"People-Oriented" Updated Management Thoughts. In the direction of people-oriented, the guiding ideology of college students management in our country has been developed and presented. College students management shows the participatory, and the mutual sharing and services has preferably permeated into it. The management of college students in China is the management of student' disciplinary discipline as well as helps students to create a good learning and living environment in more aspects. It helps students to solve their learning and living problems effectively. Under the guidance of people-oriented, the management of college students in China has been better shared with students, updated on the management notion, carried out management work centered on students' learning and living needs, and ensured students management in full swing [4]. 
The Combination Between School Management and Students Self-management. In the traditional management model, Students are passive to accept the management, which to some extent limit the freedom of students and suppress the students' personality. This kind of management model usually will stimulate the students' rebellious and increase the management difficulty, which is opponent to the "people-oriented" educational requirements. As adults, college students has already had a certain management ability. In the concept of people-oriented, fully respecting students management capacity and actively use it can mobilize the enthusiasm of students self-management and give full plays to students self-management ability. For example, some colleges and Universities transferred the focus of students management, changed the uncompromising management patterns and management ways through students organizing associations or other modes of students management by students [5]. There are some colleges and Universities will implement the management of each student body, and urge students to self-management. Putting the school management and students self-management together to improve college students management work is an important manifestation of people-oriented management new ideas [6]. "People-oriented" educational conception requires students to achieve self-education, self-management and self-service, giving full play of students' subjective initiative. Regarding promoting the comprehensive development of students as the fundamental goals and measurement standards.

Establish Thorough Practice Of Testing Standards. In essence, changing the traditional management mode, combining theory with practice, testing the truth through practice truly combine theory with practice blindly expand and extend the traditional student management model, not only cannot guarantee the student management work effects, but will play a counter-productive [7]. Therefore people-oriented guiding philosophy ideology combined students, in school management and social environment based on social development truly reflect the times and reach a management effect by examining students through social practice.

Based On Culture, Improve Students Management. Actively integrating into the concept of people-oriented in the process of cultural construction of colleges and universities can rich campus culture construction, and students can form a positive management thinking through nurturing and training [8]. For the present, the enthusiasm that many students participate in the management is not strong, and the management capacity is not high, either. Stimulate students to participate in the management work and actively adjust it through the cultural construction is the school's cultural characteristics, which reflects the concept of human nature and truly is a people-oriented school culture and school management. [9]

Establish A Comprehensive Students Management Mode. To establish a comprehensive model of students managements, we must mobilize the enthusiasm of other non-student management departments, requiring other departments of the school to participate in the management of students, and thus reflects the joint effort of all departments. Which offer a better enhance on the students management [10]. As for the students management, it is not the duty of a single department but the need for college students management and non-students management departments to work together. For the management of students, it should not only be a simple and crude traditional management model, but to play a collaboration function of management and service, doing a good job of students' management and service work.

Personnel who are engaged in students' management work are the direct implementers of students management. Their personality, quality, knowledge structure, speech and behavior will directly affect the effect of students management. Therefore, if the school wants to improve management level of students, they need to improve the overall quality of the staff of students management firstly! First of all, developing preferential policies to attract more and better talents to participate in students management work; Second, organizing business skills to enhance the relevant training from the internal improvement of the overall quality of students' management staff; Third, making relevant measurement standards from the external to promote the work level of students management staff. 


\section{Summary}

In the management of college students, students management is the key point. How to create a good learning and living environment for students, improve the overall quality of students, effectively ensure that college students in a better environment for learning is a key issues. Integrating the concept of people-oriented into the management of students, communicating to college students according to their specific characteristics and truly ensure that students management work get new development.

\section{Reference}

[1] L. Xiong. Research on Management of Student Management in Universities [J].Educational Review, 2014, (11):54-56.

[2] H.M. Huang and B. Chen. The Research on the Path of Management Reform of University Students in China based on the Development of Students' Subjects [J]. Research in Higher Education of Engineering, 2014, (05):108-112.

[3] Z.Z. Wang. The Main Point of "people-oriented" University Student Management. [J]. Heilongjiang Science, 2014, (08):114.

[4] Q. Wang . The New Model for Students Management in Colleges and Universities [J]. Journal of Liaoning Administration College, 2014, (07):90-91.

[5] J.Q. Pan, J.Q. Zhang and Y.F. Zhu. Theory of Student Management Work in Colleges and Universities under the Rule of Law and Humanistic Value Orientation [J]. Journal of Mudanjiang Teachers College (Philosophy Social Sciences Edition), 2014, (03):16-18.

[6] M.G. Gu. The Study of Management Mode of Students in the University of Higher Education [J]. Education and Career, 2014,(15):48-49.

[7] Y.K. Zhou. The Study of the Management of Students in the University of Higher Education [D]. North University of China, 2014.

[8] X. Jin. New Era College Student Management Innovation Analysis [J]. University Education, 2014, (09):169-170.

[9] F.G. Zhang. Changes in the Management System of Students in Universities based on Humanistic Orientation [J]. Science and Education (Below), 2014, (04):183-184.

[10]H. Zhang. How to Manage Student Management in Colleges and Universities [J]. Journal of Xianning University, 2014, (01):189-190. 